\title{
Azilsartan Medoxomil
}

National Cancer Institute

\section{Source}

National Cancer Institute. Azilsartan Medoxomil. NCI Thesaurus. Code C75110.

A medoxomil prodrug of azilsartan, an angiotensin II receptor antagonist with

antihypertensive activity. Upon hydrolysis, azilsartan selectively and competitively binds to the AT 1 subtype angiotensin II receptor and blocks the binding of angiotensin II to the receptor, thus promoting vasodilatation and counteracting the effects of aldosterone. Converted from ang iotensin I by ang iotensin-converting enzyme (ACE), angiotensin II stimulates the adrenal cortex to synthesize and secrete aldosterone, decreasing sodium excretion and increasing potassium excretion, and acts as a vasoconstrictor in vascular smooth muscle. 